of the Brazils and the red under wings of the genus Catocala; which in their great wing expanse, semi-looping caterpillars, and scent pencils, bridge over the gap between the Nociuina and Geometrina. Yet as their zeings want the hook, so do their fans want the pouch that conceals them in these moths. Indeed the ghost moths, and the family of the Hepialide to which they belong, want so many of those characters that characterize lepidoptera, that one is led on to the supposition that their progenitors never acquired them; and they belong to an older race, that in time past has disseminated itself from Europe to the antipodes of the Maories. Other races, as the species of Psychidae and Coleophora, whose distribution is equally great, are in their economy scarcely indeed less curious; and the worm-like females of the first, sitting on their caddis-cases composed of straws, bring us very low down indeed in the scale of insect organization and adaptation, while they seem at the same time to transport us back in geological time.

\title{
ENTOMOLOGY FOR BEGINNERS.
}

THE GREAT LEOPARD MOTH-Ecpantheria scribonia Stoll.

BY THE EDITOR.

The larva of this insect is comparatively abundant in the autumn throughout most of the Northern United States and in many parts of Canada. It is found feeding on various species of plants, but most commonly on the wild Sunflower, Heiianthus decapetalus. It is about two and a half inches long, with a shining black head shaded with reddish on the sides, and a brownish black body. Each segment has an irregular transverse row of tubercles from which spring tufts of rigid shining black hairs, while the spaces between each segment from the fourth to the tenth inclusive are banded with red, the bands being widest and most conspicuous from the sixth to the ninth inclusive. These bands are a striking feature in the appearance of the caterpillar, especially when it is coiled up as shown in figure 12 (after Riley). The color of the under side varies 
from reddish to yellowish brown, feet reddish, prolegs brown, thickly clothed with short hairs.

This larva attains its full growth in the autumn and hybernates during the winter under logs, the loose bark of decaying trees, or other suitable

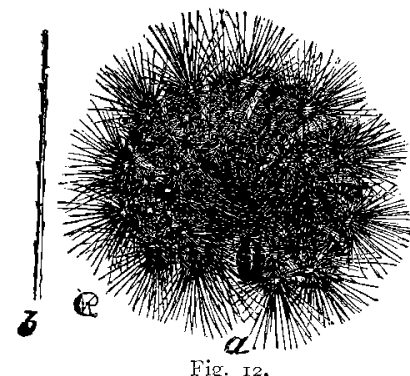

hiding places. By the genial warmth of spring it is aroused from its torpid condition and feeds for a few days upon grass, or almost any other green thing it may meet with. It then constructs a loose cocoon, within which it enters the chrysalis state.

The chrysalis is black with a beautiful bloom on its surface, which is easily rubbed off ; it has a flattened projection at its hinder extremity, which is tipped with a few bristles.

After remaining about a fortnight in the pupa state, it appears as a unique and very beautiful moth. In figure I3 (after Riley) $a$ represents

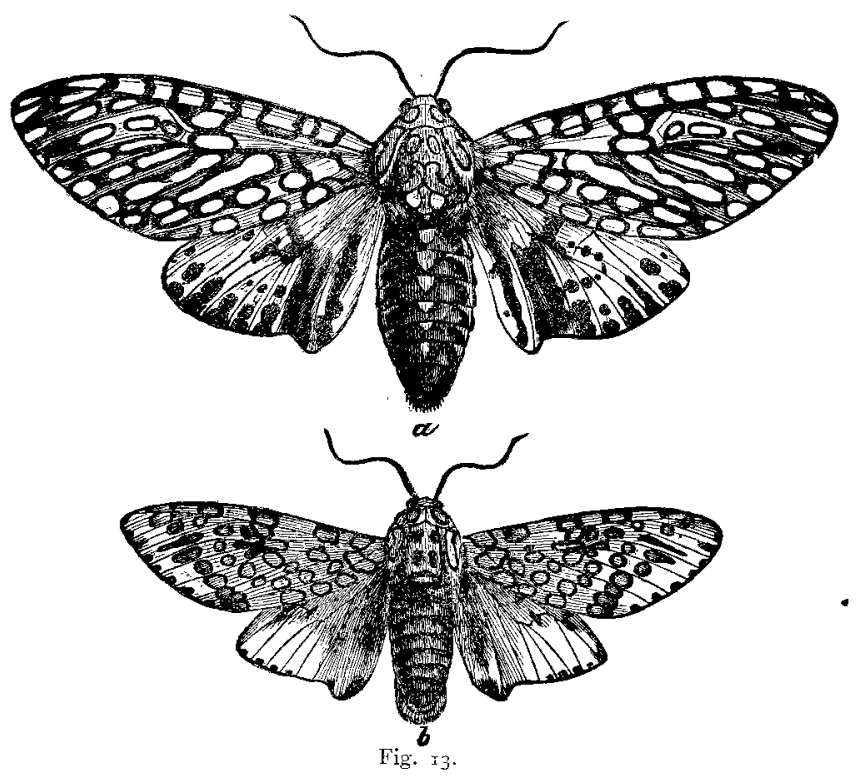

the female, $b$ the male. The wings are white, ringed, streaked and spotted with dark brown as shown in the figure. The thorax has ten or twelve 
black spots with a bluish white centre; the upper portion of the body is steel blue, streaked along the middle and sides with yellow or orange; legs white, ringed with black at the extremities. The male differs from the female mainly in his smaller size and narrower abdomen.

\section{PROFESSOR FERNALD'S SYNONYMICAL CATALOGUE OF NORTH AMERICAN TORTRICIDE.}

BY A. R. GROTE.

The reader of the Canadian Entomologist will recall the first paper on the Tortricida, by Professor Fernald, who has been kind enough to send me advance sheets of his Catalogue of the Family now being published in Philadelphia.

At the time when Professor Fernald commenced his studies he paid me the compliment of asking my advice as to the group of Lepidoptera he should work upon. In advising him to take the Tortricide, I was influenced by my belief in his patience and scientific ability. No family of Lepidoptera which I have studied, except perhaps the Phycide, are as difficult as the Tortrices, or call for more diligent examination and careful manipulation. I had been bringing together material for a study of the Tortricide, and had described a few species and the genus Phaccasiophora, when Professor Fernald wrote to me. I was thus in a position to be of the slight assistance which Professor Fernald has, I am afraid, overestimated in his original paper alluded to above. But it is difficult to overestimate the importance of Professor Fernald's work and the excellence with which it has been performed. With the valuable aid of Lord Walsingham, Professor Fernald was able to examine personally almost every one of Mr. Walker's types. The types of my friend, the late Mr. C. T. Robinson, had been placed in Professor Fernald's hands before his visit to London, and I had given hin all the material brought together by myself, so that no one was in so favorable a position for ascertaining what had been described and what was yet new among our Tortrices. Every American paper which I have seen on the family, since that time, has been issued after the material on which it was based had been determined 